\title{
The party autonomy paradigm: European and global developments on choice of forum
}

\author{
Xandra Kramer* and Erlis Themeli** \\ Author copy. This paper was published in: Vesna Lazić \& Steven Stuij, Brussels Ibis Regulation. \\ Changes and Challenges of the Renewed Procedural Scheme (The Hague/Heidelberg, Asser \\ Press/Springer 2017), p. 27-49. The page numbers of the book are indicated [ ] in the text.
}

[27]

\begin{abstract}
One of the pillars of international commercial litigation is party autonomy as it has developed over the past fifty years. In Europe, the Brussels regime established considerable freedom for parties to select the court that would have jurisdiction. The enforceability of choice of court agreements has gained ground in many countries worldwide, and the freedom to select the competent forum is exercised widely in commercial practice. Early in 2015, the new Brussels I-bis Regulation became applicable, altering the rules on choice of court. These amendments, particularly the exception to the lis pendens rule, aim at increasing the efficiency of choice of court agreements and at preventing torpedo litigation tactics. This year also marks the entry into force of the Hague Choice of Court Convention that had been adopted ten years earlier. The present paper explores the concept and development of the party autonomy paradigm from the perspective of different disciplines, and discusses the empirical evidence available on the use of party autonomy in commercial practice. It also examines the main changes brought about by the Brussels I recast and the entry into force of the Hague Choice of Court Convention, and analyses these against the background of the party autonomy paradigm, as well as their contribution to effective litigation.
\end{abstract}

\section{Keywords}

Choice of forum - party autonomy - efficiency - lis pendens - competition of courts - Brussels I-bis Regulation - Hague Choice of Court Convention

\section{Introduction}

The year 2015 - commemorating the 50th anniversary of the T.M.C. Asser Institute, to which this paper is dedicated - is an important one for party autonomy in international litigation. On 10 January 2015, the Brussels I-bis Regulation, replacing the Brussels I Regulation, became applicable. One of the main objectives of the recast of the Brussels I Regulation was to strengthen the effect of choice of court agreements, also in view of their practical importance in commerce. ${ }^{1}$ On 1 October 2015, the Hague Choice of Court Convention finally entered into force, ten years after it had been adopted. The Convention currently applies between Mexico,

\footnotetext{
* Xandra E. Kramer is a professor at the Erasmus School of Law, Erasmus University Rotterdam, kramer@law.eur.nl.

** Erlis Themeli is a PhD researcher at the Erasmus School of Law, Erasmus University Rotterdam, themeli@law.eur.nl.

${ }^{1}$ See the Green Paper on the review of Council Regulation (EC) No 44/2001 on jurisdiction and the recognition and enforcement of judgments in civil and commercial matters, COM(2009) 175 final, p. 5.
} 
and the EU Member States (with the exception of Denmark) and Singapore. A number of other countries are expected to join the Convention in the near future. Both instruments have been developed with the objective of supporting the enforcement of choice of court agreements, and thus increasing the legal certainty and efficiency of international litigation.

Over the last several decades, party autonomy has come to be increasingly important in private international law, and has become the new paradigm, both for international jurisdiction and choice of law, in particular - but not limited to - commercial relationships. In Europe, the gradual development of the possibility of selecting the court that would have jurisdiction if a dispute were to arise or has arisen between commercial parties had already started at the beginning of the last century. It is now widely accepted in most parts of the world. Party autonomy in commercial litigation has also been intensified, due to the popularity of arbitration. [29] In Europe, almost fifty years ago the Brussels Convention, and meanwhile the Regulation, rooted party autonomy firmly by ensuring the enforceability of choice of court agreements. On the global level, the Hague Choice of Court Convention would have the same potential if it were to be ratified by a substantial number of countries.

The aim of this paper is to explore the party autonomy paradigm in private international law - and choice of court in particular - from different perspectives, and to assess the European and global regulatory developments in this regard. Sect. 2 views the essence and value of party autonomy from various disciplines, including a psychological, sociological, and economic perspective, as well as in the context of private international law and litigation. On the basis of the available empirical data, certain conclusions are drawn with regard to the relevance and exercise of party autonomy by way of choice of court in practice. In Sect. 3, the new rules of the Brussels I-bis Regulation regarding choice of court are discussed, in particular with a view to enhancing the enforceability of choice of court agreements, and to increasing efficiency in international litigation. Section 4 sketches the background and basic rules of the Hague Choice of Court Convention and the interaction with the Brussels I Regulation. The paper concludes that party autonomy in private international law is inspired and supported by other disciplines. The available data show that parties value and often make use of their freedom to select the competent court, although the rationale behind their choices is not always evident. The Brussels regime has matured over the last several decades, and the recent amendments to the Brussels I-bis Regulation are generally to be welcomed. The entry into force of the Hague Choice of Court Convention is a landmark in the development towards a global enforceability of choice of court agreements relating to the benefit of international commercial practice.

\section{A paradigm on party autonomy}

\subsection{Party autonomy through the lens of other disciplines}

During the last fifty years, legal scholarship and regulations have afforded contractual parties more freedom to choose how to govern their contracts and rights. Closely related to freedom, ${ }^{2}$ party autonomy is a key element that has characterised [30] private international law in recent years. ${ }^{3}$ While being related with other terms like private autonomy and individual autonomy, ${ }^{4}$

\footnotetext{
${ }^{2}$ It has been suggested that party autonomy can play a role in implementing fundamental freedoms in the EU. If a fundamental freedom is respected in one country but not in another, an interested person can choose the law of the country that better respects the freedom, and can later ask the other countries to respect that freedom by virtue of mutual recognition. See Weller 2015, pp 75-77.

${ }^{3}$ The term 'party autonomy' is a recent one, but the practice of choosing a court for resolving disputes seems to be an ancient invention, dating back to Ptolemaic Egypt (Symeonides 2013, p 875). Without disputing the authenticity of the claim, it can be said that sporadic and isolated choice of court agreements, where party autonomy is used, does not constitute an established practice that endures over time and becomes a legal institution.

${ }^{4}$ Both are considered to be the base of private law (Smits 1998, p 330).
} 
party autonomy is used mainly to describe the possibility that parties to a contract have to choose the mechanisms and the location where their disputes will be resolved and/or the law applicable to a contract or other legal relationship. ${ }^{5}$ Party autonomy is the joint product of two or more parties. A choice of court made by one person is an expression of that person's individual autonomy, and the parties' autonomy is created only in conjunction with the individual autonomy of another person. Therefore, party autonomy is in essence the combination of joint individual autonomy, which is expressed in a choice of court or law. ${ }^{6}$ From a psychological perspective, freedom is relative to each party and to the social setting of the subject. In some settings, the boundary between the individual's decision-making sphere and that of society is not evident. It is unclear where the group ends and where the individual begins. In these instances, it becomes more difficult to determine who is making the choice. ${ }^{7}$ To illustrate this, one might consider a party that wants to make a choice of forum, but the community where that party conducts its business and interactions suppresses or distorts the freedom to make that choice. ${ }^{8} \mathrm{~A}$ number of industries and branch organisations require their members to use certain fora, and in this manner they suppress their members' party autonomy. It is understandable that while parties are allowed a formal freedom, their social setting might require a certain conformity, and thus in fact distort their party autonomy.

Party autonomy has a sociological connotation as well, and, in a certain manner, it relates to historical events like the Scottish Enlightenment and the French Revolution. These events introduced and further developed the notions of laissez-faire and individual freedom in many aspects of life. While in England these movements inspired the creation of the 'freedom of contract' theory, ${ }^{9}$ which holds that parties are free to stipulate their own contractual terms without the interference of the state, in Germany they created the idea of a liberalistic process. ${ }^{10}$ The $[31]$ core of this idea was that individuals were free in relation to the government, and at liberty to use their independence within certain boundaries. In civil procedure, this allowed parties to choose their own procedural steps, which included the choice of court, and to dispose their procedural rights as they wished. On the one hand, the liberalistic process implied that the state was neutral and passive, and the conflict between the parties was decided on what they presented, without considering the material truth. On the other hand, the parties were considered equal and able to protect themselves, which in fact was not true.

The liberalistic process idea described above implies that parties have the same bargaining power and the same qualities in creating and expressing their choice of court. In a perfect world, parties would be equal, and their choice of court would be the result of a combined effort to find an optimal solution. While a perfect distribution of power and quality between parties is ideal in principle, in reality it is not. In many cases, one of the parties has more bargaining power than the other, or is more qualitative, or both. This means that the weaker party's autonomy is distorted, if not neutralised, and the result of the negotiation largely reflects the will of the stronger party. ${ }^{11}$ Of course, this creates social as well as economic problems, which governments try to avoid. In response to this problem, a social process idea

\footnotetext{
${ }^{5}$ Rühl 2007, Choice of Law and Choice of Forum in the European Union: Recent Developments. Social Science Research Network, p. 4. http://papers.ssrn.com/sol3/papers. cfm?abstract_id=1604615. Accessed 6 October 2016.

${ }^{6}$ Symeonides 2013, pp 882-885.

7 Schwartz 2000, p 84.

${ }^{8}$ Forced choice or related phenomenon can be conscious, as in the case of a party that knows that even though $\mathrm{s} /$ he has unlimited freedom to choose, in fact, the choices $\mathrm{s} /$ he can make are limited. Unconscious forced choice occurs when a party is not aware of all the available possibilities (Salecl 2011-2012; Salecl 2009, p 168).

${ }^{9}$ Low 2013, p 365.

${ }_{10}^{10}$ Ervo 2014, pp 389-396.

11 Symeonides 2013, p 885.
} 
was developed in Germany. ${ }^{12}$ According to this notion, the court, and legal systems in general, should not be neutral, but should assist in and take into consideration the creation of equality in the community. To achieve this, weaker parties are offered special protection in procedures, which includes limiting the party autonomy in instances where weaker parties might be endangered by the superiority of the other party. ${ }^{13}$ This means that parties can exercise their party autonomy only in cases where their bargaining power is evidently not unbalanced. It does not mean that the bargaining power should be equal, but that the difference should not be such as to allow one party to impose its will on the other. This protection of weaker parties has gained firm ground in European private international law, as is noteworthy in, among other things, the Brussels I-bis Regulation, which strictly limits the effect of a choice of court made by the stronger party in consumer, insurance, and employment contracts. ${ }^{14}$ [32]

Viewed from an economic standpoint, party autonomy is considered to increase efficiency, ${ }^{15}$ since parties that have multiple options are better able to allocate their resources and serve their needs. If the parties' choice does not reduce the welfare of third parties, the result will be Pareto efficient; if the choice increases the benefits of the parties more than it decreases third parties' benefits, it will be Kaldor-Hicks efficient. ${ }^{16}$ For governments, party autonomy is also a way to observe how users of their services vote with their feet. This would give them information as to what certain services users want, and where, and facilitate the allocation of their resources. ${ }^{17}$ Furthermore, some states try to attract users of the legal system, which would make them enter into a competition with other states. ${ }^{18}$ Competition between states or jurisdictions might lead eventually to innovation and improvement of the services they offer. ${ }^{19}$ This, however, does not mean that party autonomy brings only benefits; as with many activities, it can create externalities that need to be mitigated. ${ }^{20}$ If the externalities created are internalised by the parties, they will tend to make efficient use of their party autonomy: for example, by choosing a jurisdiction that is costly, the parties will suffer from the high costs, in which case they will either try to reduce costs or make a better - more efficient - choice of court. The problems start in the event that externalities are not internalised, resulting in the costs being dumped to third parties, and in the state most probably having to step in to mitigate the problem. ${ }^{21}$ Therefore, while supporting party autonomy, governments should try to take

\footnotetext{
12 The social process idea was a response to the prepotency of stronger parties. Their power was manifested not only during the negotiation phase but also in the due course of the process. By dragging out the process, or by forcing costs to escalate, stronger parties weaken the chances of weaker parties having a successful outcome. According to the notion of social process, civil procedure should take this into account, and thus provide for a shorter process and for the protection of negotiation processes, as well as give judges the discretion to evaluate the social consequences of his/her decisions. Ervo 2014, pp 396-399.

${ }^{13}$ Eidenmüller 2011, p 721.

14 See Art. 25(4) read together with Art. 15, 19, and 23 of the Brussels I-bis Regulation. In relation to choice of law, see Art. 6(2) and 8(1) Rome I Regulation on consumer and employment contracts, and to a lesser extent Art. 5(2) and 7(3) Rome I Regulation on passenger transport and insurance contracts.

${ }^{15}$ Rühl 2007, Choice of Law and Choice of Forum in the European Union: Recent

Developments. Social Science Research Network, p. 4, http://papers.ssrn.com/sol3/papers.

cfm?abstract_id=1604615. Accessed 6 October 2016; Efficiency of states is still debatable, see

Michaels 2008, p. 87, 102.

${ }^{16}$ Rühl 2007, Choice of Law and Choice of Forum in the European Union: Recent

Developments. Social Science Research Network, p. 5, http://papers.ssrn.com/sol3/papers. cfm?abstract_id=1604615. Accessed 6 October 2016.

17 This is also the essence of Tiebout's theory (Tiebout 1956). For a critical discussion on the role of the state as a rational actor that tries to maximise efficiency, see also Michaels $2008, \mathrm{p} 82$.

${ }_{18}$ As Peters points out, party autonomy is one of the conditions for the existence of competition involving jurisdictions. Peters 2014, p 57; Kramer 2014, no 41.

${ }_{19}$ Michaels 2008, p 80, claims that the main purpose of party autonomy is to dismiss ineffective laws.

20 Michaels 2008, p 87.

${ }^{21}$ Michaels suggests that party autonomy is desirable only in the event that it does not create transaction costs for third parties. It can be said that a Kaldor-Hicks efficiency is still desirable - or, in other words, if the costs to the other party are less than the costs of the parties expressing the party autonomy. See Michaels $2008, \mathrm{p} 87$.
} 
into account the possible externalities resulting from this autonomy, while parties should consider the externalities created by their own actions.

When choosing a forum for the resolution of disputes, parties are not simply selecting a location they might want to visit as tourists. Indirectly, they are also [33] choosing the procedure that will be applied to solve the conflict - whether in court or in an ADR venue. It is obvious that procedure has a tremendous impact on the outcome of the process. Therefore, expressing party autonomy by making a choice of court is extremely important. ${ }^{22}$ This choice allows parties to choose not only from among state courts, but also from among those courts and private dispute resolution mechanisms. Thus, parties can 'escape' from governmentorganised conflict resolution and choose more efficient ${ }^{23}$ mechanisms. It is this freedom that creates the basis for the functioning and organisation of arbitration, mediation, and other forms of private dispute resolution mechanisms. Furthermore, the existence of such mechanisms can have a positive and a twofold impact on governments: firstly, it releases the pressure on state courts, which in some cases face an enormous workload; secondly, it creates a forum or fora - that is competitive with the state court, which might spur their reforms and development.

Party autonomy is instrumental in different fields of law, although in some areas including antitrust law and environmental law, where public interest issues are involved - it is limited or non-existent. ${ }^{24}$ Party autonomy relates to the principle of personal private autonomy, which is the right of a person to decide his/her own future and the modalities to pursue it, with or without limited interference from the state. It is an expression of private autonomy, which gives parties the right to choose their legal rights and obligations, ${ }^{25}$ and it enhances legal certainty in situations where multiple options are available. ${ }^{26}$ Nevertheless, party autonomy should not be used as a means of polluting legal certainty or threatening the defences of the weaker parties, or as a way of overriding other rights. ${ }^{27}$ In other words, it is necessary to strike a balance between parties' autonomy and other rights.

\subsection{Party autonomy in private international law}

In private international law, party autonomy may be considered one of the greatest achievements of the $20^{\text {th }}$ century. ${ }^{28}$ Even though it is accepted in many jurisdictions, party autonomy is more widely accepted in Europe and North America, [34] compared to, in particular, Latin America. ${ }^{29}$ In Europe, parties' autonomy in the choice of court had been accepted long before the Brussels I Regulation ${ }^{30}$ or its predecessor the Brussels Convention. ${ }^{31}$ However, the Brussels Convention has been celebrated as the first step towards formalising party autonomy at the European level. Enlightened by the lessons learned from the Brussels Convention, the Regulation did a better job of framing the principle of party autonomy in its Art.

\footnotetext{
22 In many cases, parties make a choice of law, and in doing so they follow the choice of court. It is still not clear how often this happens, but it is understandable why it might.

${ }^{23}$ Apart from efficiency, 'escaping' can also be justified by the parties' desire to find mechanisms of a better quality or that are more neutral than those offered by the government.

24 Trachtman 1993, pp 60-61; Symeonides 2013, p 875-876.

25 Sieger 2011, p 197.

${ }^{26}$ Rühl 2007, Choice of Law and Choice of Forum in the European Union: Recent

Developments.Social Science Research Network, p. 4, http://papers.ssrn.com/sol3/papers. cfm?abstract id=1604615. Accessed 6 October 2016; Eidenmüller 2011, p. 710.

27 Magnus 2012, p 91.

28 Brand 2014, p 375.

${ }^{29}$ Symeonides 2013, p 876; Beaton 2012, p 268.

${ }^{30}$ Council Regulation (EC) No 44/2001 of 22 December 2000 on jurisdiction and the recognition and enforcement of judgments in civil and commercial matters, OJ L 12, 16.1.2001, p 1-23.

31 Convention on jurisdiction and the enforcement of judgments in civil and commercial matters (Consolidated version) - 1968 Brussels Convention OJ C 189, 28.7.1990, p 2-24.
} 
23, while party autonomy has been strengthened further under Art. 25 of the new Brussels Ibis Regulation. ${ }^{32}$ In fact, party autonomy can be regarded as one of the founding principles of the Brussels I-bis Regulation, which is also evidenced by the Regulation's recitals, which underline the importance of parties' autonomy. ${ }^{33}$ One might even consider Art. 25 on choice of court to be the default rule for the Brussels I-bis Regulation, ${ }^{34}$ in which case the other provisions can be considered exceptions to the main rule. ${ }^{35}$ These exceptions are stated carefully in the Regulation in order to avoid further limitations to party autonomy by courts or even the parties themselves. ${ }^{36}$ The limitations to, or the exclusion of, party autonomy are aimed primarily at protecting weaker parties and at avoiding externalities for third parties. Furthermore, governments can limit party autonomy to protect public order, ${ }^{37}$ as is also embodied in Art. 24 of the Brussels I-bis Regulation. The possibility of limiting party autonomy in the interest of weaker parties, and the general principle that parties can dispose their rights, indicates a tension between public and private law. ${ }^{38}$ Unless the legislator provides rules to resolve this tension, it is discharged to the courts, which should find the [35] appropriate balance between party autonomy, the respect regarding other rights, and public order. ${ }^{39}$

At the global level, a true landmark for party autonomy and the enforcement of choice of court agreements was the entry into force of the Hague Convention on Choice of Court Agreements in Mexico and the EU Member States, with the exception of Denmark, on 1 October 2015. ${ }^{40}$ Meanwhile, the Convention has also entered into force for Singapore (1 October 2016). It was already signed by the US (in 2009) and recently by Ukraine (in 2016). ${ }^{41}$ One of the reasons for the adoption of the Convention by the EU, as is also mentioned in the Council's decision to sign the Convention, is the fact that the Convention can serve as an important tool in furthering and promoting party autonomy regarding the choice of court for international commercial contracts.

The freedom given to parties by private international law instruments has its dark side as well. While providing the freedom to choose the court, these legal instruments presume a certain fair-play between the parties: namely, that parties will select the court that best suits their combined interest. As has been rightly pointed out, there is always the risk of an information asymmetry, ${ }^{42}$ and one of the parties might possess more bargaining power. ${ }^{43}$ Moreover, party autonomy can also be disrupted by litigation tactics on the part of one of the parties, resulting in negative expressions of forum shopping, and eventually undermining party autonomy. One

\footnotetext{
32 Regulation (EU) No 1215/2012 of the European Parliament and of the Council of 12 December 2012 on jurisdiction and the recognition and enforcement of judgments in civil and commercial matters, OJ L 351, 20.12.2012, p 1-32.

${ }^{33}$ Recitals 14, 15, and 19 affirm exactly this. Despite some restrictions, party autonomy should be respected. Nielsen 2013, p 513.

34 There are two opposing views: the private law view considers party autonomy to be the default position, which can be derogated in the event of certain conditions, while the international law view considers the objective determination of the court to be the default position, and party autonomy to be an exception to the rule (Michaels 2008, p 95).

35 Magnus 2012, p 84; Brand 2014, p 375.

${ }^{36}$ Ferrero 2014; Zimmermann 2006, p 85; Gottschalk 2007, p 196.

${ }^{37}$ Brand 2014, pp 378-379; for the law and economic perspective of this, see Beaulier 2005, p 183.

38 Michaels 2008, p 74.

${ }^{39}$ Strong 2014, p 1060. Art. 24 of the Brussels I-bis Regulation provides an exhaustive list of cases where the parties' autonomy has been restricted for public policy reasons. In a different fashion, Art. 6(c) of the Hague Convention allows the courts more discretion to dismiss a choice of court by the parties. This discretion should be justified by a manifested injustice or be manifestly contrary to the public policy of the State of the court seized.

${ }^{40}$ Council Decision 2009/397/EC of 26 February 2009 on the signing on behalf of the European Community of the Convention on Choice of Court Agreements, OJ 2009, L 133/13.

${ }^{41}$ Status available at $<$ http://www.hcch.net/index en.php?act=conventions. status2\&cid=98 $>$ accessed 6 October 2016.

42 Dammann and Hansmann 2008, pp 15-18.

43 Basedow 2013, pp 20-21.
} 
such notorious instance is the Gasser case ${ }^{44}$ in which Gasser, an Austrian company, and MISAT, an Italian company, had chosen the Austrian courts in their contract. When a conflict emerged, MISAT filed a case in an Italian court for a declaratory judgement before Gasser brought its claim for the payment of invoices in the Austrian court on the basis of the choice of court agreement. The Court of Justice decided that a court seized second, even if chosen in the choice of court agreement, must stay proceedings until the first seized court has declared that it has no jurisdiction. This strict lis pendens rule causes the party autonomy to be blocked or frozen. Such tactics involving a rush to the court to frustrate [36] proceedings have been infamously referred to as 'Italian torpedo', and have been justly criticised as being abusive and hampering justice and trade. ${ }^{45}$ This case shows as well that the principle of party autonomy can be overridden by other principles, such as mutual trust within the EU. Fortunately, in the Brussels I-bis Regulation, this 'gap' in the system has been closed. ${ }^{46}$

Parties that have the possibility of choosing a court will select the one that best serves their interests. Governments that try to attract parties to their jurisdictions tend to offer procedural advantages to parties, which can become enormous assets for the outcome of the case. Lenient procedures and application of the law can benefit litigating parties, but can also result in a deterioration of the procedures and courts. Relaxing legal provisions and protection drags governments into a race-to-the-bottom, ${ }^{47}$ as a consequence of which, weaker parties lose their legal and procedural protections, and become vulnerable with regard to their stronger opponents. Ironically, the race-to-the-bottom starts as a result of the parties' autonomy, which enables them to search for more lenient rules. Lenient laws and procedures, which with their superior advantages can distort or neutralise the weaker parties' autonomy, favour few parties. However, some scholars consider the prospects of a race-to-the-bottom as not very likely. ${ }^{48}$ In a diametrically opposed scenario, party autonomy and governments that try to attract litigating parties would end up creating a race-to-the-top, which would presuppose higher standards, better procedures, better courts, and a more attractive look for the courts. The prospect of a race-to-the-top might be beneficial for weaker parties, and might better protect the expression of party autonomy. Nevertheless, the discussion with regard to race-to-the-bottom or race-tothe-top remains theoretical, as little or no empirical evidence of their existence has been found. ${ }^{49}$

\subsection{Empirical data on choice of court}

That party autonomy is also exercised in practice is supported by a number of empirical studies. Remarkably, a survey conducted by a group of researchers at Oxford University ${ }^{50}$ found that the percentage of respondents that considered the choice of court 'very important' was higher than that regarding choice of law. The results of the survey demonstrate that 61 percent of the respondents considered the [37] choice of court to be 'very important', while 48 percent responded that they had 'often' opted for a foreign court. Another survey, conducted by researchers at the University of Basel, found that parties in commercial contracts considered party autonomy to be the third most important factor when choosing the substantive

\footnotetext{
44 ECJ 9 December 2003, Case C-116/02, ECR 2003 I-12693 (Erich Gasser GmbH v MISAT Srl).

45 Fentiman 2007, pp 489, 495.

46 See further Section 3.3.

47 Visscher 2012, p 80; Wagner 2013, pp 374-375.

${ }^{48}$ Kramer and Van Rhee 2012, pp 5-6, while in disagreement with Visscher that a race-to-the-bottom can be stopped or checked through the harmonisation of civil procedure, consider that a race-to-the-bottom in the EU can be prevented by existing procedural standards.

${ }^{49}$ Visscher 2012, p 81.

${ }^{50}$ Available at <http://www.law.ox.ac.uk/themes/iecl/ocjsurvey.shtml> accessed 31 August 2015.
} 
law to govern their contract. ${ }^{51}$ Respondents considered only factors connected to legal certainty to be more important than party autonomy. Practices of restricting party autonomy were, among others, considered to be reasons for avoiding jurisdictions that practised them. ${ }^{52}$ Another study, conducted by the consultancy firm PWC and the Queen Mary University in London in $2013,{ }^{53}$ found that the choice of forum option was applied often In fact, disputes that could not be resolved amicably were referred equally to arbitration and litigation, with 47 percent each. The remaining cases were referred to 'expert determination/adjudication'. In other words, parties in approximately half of the cases made a choice of court, and probably even more did so if one were to discount the cases in which a choice of court was not possible.

While data from surveys show that the business sector is highly appreciative of party autonomy, the reasons for choosing one court over another remain unclear. The survey conducted by the Oxford researchers contained some questions related to the choice of court. ${ }^{54}$ As mentioned above, respondents valued the possibility of choosing a court for their disputes. When asked about their preferred court, England (17\%), Italy (12\%), Germany $(10 \%)$, and Switzerland (10\%) were among the top choices. ${ }^{55}$ If these answers were controlled for the home country of the respondents, Switzerland (19\%), England (14\%), France (13\%), and Germany (10\%) were the most preferred. As can be seen, there is a difference between the two results, which speaks of a home bias for certain counties like England, Italy, the Netherlands, Spain, and Poland. ${ }^{56}$ Jurisdictions like Switzerland and France have a better result by removing the home bias, while the percentage for Germany remains the same. These results suggest that the home bias is not spread uniformly, and some jurisdictions fare better without it. Asked about the factors taken into account when making a choice of court, respondents considered 'quality of judges and courts', 'fairness of the outcome', 'corruption', ${ }^{57}$ and 'predictability of the outcome' to be the top four. The same factors [38] were considered the most important in instances of trying to avoid a specific court. Apparently, the factors taken into consideration are consistent for choosing and avoiding courts, but the survey does not show whether both parties are well informed. The question is whether parties do in fact consider all the options. Do they have the means and the tools to quantify or to assess the relevant factors to make a choice of court? Are judges in Switzerland less corrupt than their colleagues in the Netherlands, Sweden, or Germany? Is the quality of judges higher in England than in Germany or Italy? The same questions can be asked about all other factors that some parties take into account. By analysing all known empirical researches on choice of forum, Vogenauer concludes that parties are heavily influenced by 'familiarity', 'neutrality', and 'image' of the forum. ${ }^{58}$ These are not primarily legal or true qualitative considerations, but are related to market conformity (image and familiarity) and perceived quality (neutrality and image). Clearly showing his disappointment in these findings, Durand-Barthez considered the choice of court in Europe to be afflicted by psychological factors rather than purely technical ones. ${ }^{59}$ Indeed, the fact that these considerations seem to outweigh the intrinsic quality of the court system as such is somewhat disenchanting. ${ }^{60}$ It might be disappointing for lawmakers and

\footnotetext{
51 With 46.7 percent of the respondents, party autonomy came third after 'legal rules that were easy to ascertain' (68.72 percent) and 'body of case law that facilitates interpretation of legal rules' (53.74 percent). Moser 2015 , p 43. 52 Moser 2015, p 46-47.

53 International Arbitration Survey 2013: Corporate choices in International Arbitration, available at $<$ http://www.pwc.com/arbitrationstudy> accessed 31 August 2015.

54 The survey conducted by Vogenauer and Weatherill did not contain questions related to choice of court or choice of forum.

${ }^{55}$ Arbitration was chosen by 16 percent of the respondents; however, it is not included in this analysis because it is not a state-organised court.

56 Not shown here; see question 30 and 30.1 of the survey, footnote 50.

${ }^{57}$ Or rather 'lack of corruption'.

58 Vogenauer 2013, pp 256-263.

59 Durand-Barthez 2012.

60 Kramer 2014, no 31.
} 
governments that, on the face of it, factors other than legal ones can influence - even dominate - a party's choice. Attempts by governments to attract parties might be futile, considering the cold reaction on the part of lawyers. Scholars that cherish competition of jurisdictions as an incentive to improve the quality and efficiency of courts must comfort themselves with the thought that this situation might change one day. Hope is always the last thing to perish, and we would like to think that a more active role on the part of competing governments might succeed in changing the attitude of lawyers and corrode the primacy that English courts enjoy in the choice of court.

\section{Choice of forum in the Brussels I-bis Regulation}

\subsection{The Brussels regime: development and shortcomings}

The Brussels regime - from the Brussels Convention to the Brussels I Regulation ${ }^{61}$ and now the Brussels I-bis Regulation - has secured the validity and enforcement of choice of court agreements. The choice of court provision, according to the Court of Justice, is based on the independent will of the parties in deciding which courts are to have jurisdiction for a dispute that comes under the scope [39] of the Brussels regime. ${ }^{62}$ The forum selection embodies party autonomy, and aims at ensuring legal certainty as to which court will have jurisdiction in the event of a dispute. In the following versions, amendments have been made to make the formal requirements more flexible and to adapt these to commercial practice. While the original version of the Convention of 1968 only allowed a choice of court that was agreed or evidenced in writing, the 1978 Accession Convention incorporated the conformity with international trade uses (e.g. a reference to standard branch conditions), and with the 1989 Accession Convention, the form that accords with parties' practices. ${ }^{63}$ In addition, the Brussels I Regulation equalled communication by electronic means that provide a durable record to a written agreement.

From the Heidelberg report, evaluating the Brussels I Regulation, it is clear that the provision on choice of court agreements generally functions well. Several persisting problems in the application in the Member States were identified, ${ }^{64}$ most of which were picked up in the Green Paper ${ }^{65}$ and in the following Commission proposal, ${ }^{66}$ and have been tackled in the Brussels I-bis Regulation. ${ }^{67}$

A general issue concerned the functioning of the Brussels I Regulation in the international legal order, in particular the scope of the rules, including the choice of court provision, vis-à-vis third country parties. Connected to this is the relation to the Hague Choice of Court Convention that was signed by the European Union in 2009, since this Convention contains rules that are not in line with the scheme of the Brussels I Regulation. Another shortcoming of the Brussels I Regulation was that it did not resolve the substantive validity of choice of court agreements. While the formal validity has been exhaustively regulated, ${ }^{68}$ and has been further crystalised by a series of rulings of the Court of Justice, a uniform rule regarding the substantive validity was lacking. The most pressing issue that was brought somewhat excruciatingly to the surface by the Gasser ruling of the Court of Justice concerned

\footnotetext{
${ }^{61}$ Along with the Lugano Convention of 1988 and 2007.

62 ECJ 9 November 1978, Case 23/8, ECR 19782133 (Nikolaus Meeth v Glacetal).

${ }^{63}$ See also Garcimartin 2015, no 9.03, pp 278-279.

64 Hess, Pfeiffer, and Schlosser 2007, no 374-397.

65 See footnote 1.

66 See extensively on the Commission proposal Magnus 2012, 83-102.

67 For a discussion of the new choice of court provision, see inter alia Hartley 2013, pp 309-316.

68 See Art. 23(1) Brussels I Regulation, now included in Art. 25(1) Brussels I-bis Regulation.
} 
the strict application of the lis pendens rule. ${ }^{69}$ The priority of this rule enabled a party to frustrate the effectiveness of the choice of court agreement by bringing the case elsewhere by way of delaying tactics, generally referred to as torpedo actions.

The new rules on choice of court and lis pendens in the Brussels I-bis Regulation will be discussed briefly in the following subsections. [40]

\subsection{Extended scope, substantive validity rule, and severability clause}

The scope of the jurisdiction rules including that of the choice of court provision was discussed intensively during the negotiations on Brussels I. The Commission's proposal to extend the scope of the other jurisdiction rules to third country defendants ${ }^{70}$ was not generally adopted, ${ }^{71}$ but the proposal to widen the territorial reach of the provision on choice of court agreements was. Art. 25 Brussels I-bis no longer requires that one of the parties be domiciled in an EU Member State; it applies to choice of court agreements in favour of the courts of a Member State regardless of the domicile of the parties. ${ }^{72}$ This extension of the scope of applicability of this provision is to be welcomed, as it now covers all instances in which parties have selected the courts of an EU Member State. ${ }^{73}$ However, the choice of court for a third State court is still not regulated by Brussels I-bis. In principle, these continue to be governed by the national law of the Member States, subject to the applicability of the Lugano Convention, the Hague Choice of Court Convention, or another (bilateral) convention. ${ }^{74}$ As party autonomy is one of the primary objectives of the Brussels regime, a Member State seized notwithstanding a choice of court in favour of a third court cannot ignore such a choice, thereby limiting party autonomy. As the Court of Justice made clear, a court seized should in such a case assess the validity of the clause according to the applicable law, including the conflict of law rules. ${ }^{75} \mathrm{~A}$ certain reflexive effect of the choice of court provision cannot be denied. ${ }^{76}$ As Garcimartin has rightfully assumed, if a choice in favour of a non-EU Member State were to lead to the non-application of other jurisdiction rules of the Regulation, the choice should satisfy the formal requirements of Art. 25(1) and not be contrary to the protective and exclusive jurisdiction as referred to in Art. 25(4) Brussels I-bis Regulation. ${ }^{77}$

A second adjustment is the introduction of a provision on the substantive validity of a choice of court agreement. Art. 25(1) refers to the law of the Member State of the chosen court. The Commission aimed at introducing a harmonised conflict-of-law rule, since there was no uniformity as to the law to be applied to [41] questions of substantive validity. As Recital 20 clarifies, the 'law of the Member State' includes the choice of law provisions of that Member State, which is in line with the Hague Choice of Court Convention. ${ }^{78}$ It is submitted that this rule is highly inefficient in the European context, as the Rome I Regulation excludes choice of court agreements from its scope, and consequently there is no uniform conflict of law rule designating the applicable law to the validity of the agreement. ${ }^{79}$ This means that Member

\footnotetext{
69 ECJ 9 December 2003, Case C-116/02, ECR 2003 I-14693, (Erich Gasser GmbH v MISAT Srl).

70 Proposal for a Regulation of the European Parliament and of the Council on judgments in civil and commercial matters, $\operatorname{COM}(2010) 748, \mathrm{p} 8$ and Art. 4.

${ }^{71}$ Only in relation to consumer and employment contracts; see Art. 18(1) and in a more limited manner, Art. 21(2) Brussels I-bis Regulation.

72 See Art. 25(1) Brussels I-bis Regulation.

73 This is also in line with the scope of the Hague Choice of Court Convention. See Section 4.1.

${ }^{74}$ See also ECJ 9 November 2000, Case C-387/98, ECR 2000 I-9337 (Coreck Maritime v Handelsveem).

${ }^{75}$ ECJ 9 November 2000, Case C-387/98, ECR 2000 I-9337 (Coreck Maritime v Handelsveem), point 19.

${ }^{76}$ See inter alia Stone 2014, p 185, referring to the 'implied reflexive effect' of this provision.

77 Garcimartin 2015, no 9.15 and 9.15, p 281.

${ }^{78}$ Art. 5(1) Hague Choice of Court Convention. From the explanatory report, it is clear that 'the law of that State' in this provision includes the choice of law rules; see Hartley and Dogauchi 2007, 43.

${ }^{79}$ See Art. 1(2)(d) of Regulation (EC) 593/2008 on the law applicable to contractual obligations, OJ 2008, L $177 / 6$.
} 
States will continue to use their own choice of law rules, and will either apply the lex fori, the lex causae, or a combination of these. ${ }^{80}$

The third amendment to the provision on choice of court is the codification of the severability rule. Art. 25(6) provides that the validity of the choice of court agreement cannot be contested solely on the ground that the contract in which the clause is concluded is not valid. This rule is not new, as it affirms the case law of the Court of Justice. ${ }^{81}$ It is a wellestablished principle that aims to avoid a situation in which the invalidity of the main contract invalidates the choice of court agreement, thus creating uncertainties as to the court having jurisdiction. The choice of court agreement should be treated as an independent agreement, as Art. 25(6) specifies, and the validity of this agreement should be assessed on its own merits. The same rule is included in the Hague Convention. ${ }^{82}$

\subsection{Reversing the lis pendens rule: mutual trust, competition, and efficiency}

The most debated and important novelty in the Brussels choice of court regime is the priority that the forum clause has obtained over the lis pendens rules. According to Art. 31(2) Brussels I-bis, any court seized other than the one exclusively chosen should stay its proceedings until the chosen court declines jurisdiction. If the chosen court accepts jurisdiction, any other court seized shall decline jurisdiction (Art. 31(3) Brussels I-bis). An exception is made for insurance, consumer, and employment contracts where the weaker party is the claimant and the choice is invalid pursuant to Section 3, 4, or 5 (Art. 31(4) Brussels I-bis). [42]

In the background of this amendment is the practice of torpedo actions that were unsatisfactorily facilitated by the ruling of the Court of Justice in the Gassercase, as described above in Section 2.2. Relying heavily on mutual trust and on the implied equality of courts each can rule on its own jurisdiction - the Court of Justice upheld the 'first seized' rule despite the fact that a party willingly seized a court other than the one selected, thereby freezing the jurisdiction of the chosen court. The fact that it might take years for the adjudicated Italian court to decide on the question of jurisdiction before it assumedly declines jurisdiction, in view of the choice of court agreement in favour of the Austrian court, did not change this. The Court ruled that the lis pendens provision could not be derogated from, not even when the duration in the court first seized was excessively long. The 'competition' between courts for international commercial disputes takes a negative course in these types of situations. A party can wilfully address a slow court, with the intention of blocking the jurisdiction of the mutually chosen court for a long period of time in order to frustrate effective dispute resolution or to force a settlement. ${ }^{83}$

This ruling has rightfully been heavily criticised, and has urged the Commission to more effectively protect autonomy. ${ }^{84}$ Several options were put forward, including improving the communication between courts in the case of lis pendens, imposing a time limit on giving a decision on jurisdiction, or granting a right to damage in the case of violation of a choice of court agreement. ${ }^{85}$ The preferred option, however, was to make an exception to the lis pendens rule, and thus give priority to the chosen court. This rule is also in line with the Hague Choice of Court Convention. ${ }^{86}$ Recital 22 clarifies that this exception to the lis pendens rule is intended to enhance the effectiveness of exclusive choice of court agreements, and to avoid abusive litigation tactics. The chosen court is given priority to decide on the validity of the

\footnotetext{
${ }^{80}$ Nielsen 2013, 523. See more extensively Garcimartin 2015, no 9.62- 970, pp 295-298.

${ }^{81}$ ECJ 3 July 1997, Case C-269/95, ECR 1997 I-3767 (Benincasa v Dentalkit).

82 See Art. 3(d) and 15 Hague Choice of Court Convention.

83 Garcimartin 2015, no 11.42 , p 337.

84 See inter alia Hartley 2005, pp. 322-335; Dickinson 2010, 295-296.

85 Green Paper, p 4-5.

86 See Art. 5(2) Hague Choice of Court Convention.
} 
choice of court agreement, and the non-chosen court that was seized first must stay the proceedings. Giving priority to the chosen court rather than the court first seized is to be welcomed, as it reinforces party autonomy and contributes to a more efficient dispute resolution.

\section{The Hague Choice of Court Convention}

\subsection{A long way down the road}

The Hague Choice of Court Convention is the result of a long and bumpy process of negotiations started on the initiative of the United States in 1992, on what was [43] intended to result in a 'judgment convention'. ${ }^{87}$ As is well known, a 1999 draft of the mixed convention, including rules on recognition and enforcement coupled with a white, grey, and black list of jurisdiction grounds, raised substantial objections from the side of the US and a number of other countries. These objections concerned both the format of the draft convention, which resembled too greatly the double treaty format of the Brussels regime, as well as the content of many of the proposed jurisdiction rules to guide the enforcement. ${ }^{88}$ The project was eventually downsized to a framework on choice of court agreements for which, thanks to the exhaustive diplomatic efforts of the Permanent Bureau of the Hague Conference, common ground could be found. The Convention was finally adopted on 30 June 2005.

It then took ten more years for the Convention to become applicable after the two required ratifications had been obtained, from Mexico in 2007 and eventually the European Union in 2015. ${ }^{89}$ Since 1 October 2015, the Hague Choice of Court Convention has been applicablein Mexico and the EU Member States (with the exception of Denmark), and since 1 October 2016 in Singapore, to exclusive choice of court agreements that are concluded after this date.$^{90}$ The substantive scope is more limited than that of the Brussels I-bis Regulation. In its Art. 2, it excludes consumer contracts and a number of other contracts, including transport contracts, specific maritime claims, anti-trust, and nuclear liability, as well as most types of claims based on tort or delict (personal injury, damage to tangible property, intellectual property infringements). Contrary to the Brussels I-bis Regulation, the Hague Convention applies only to exclusive choice of court agreements. ${ }^{91}$ For the application, it is required that the chosen court be that of a State that is a party to this Convention. ${ }^{92}$

\footnotetext{
87 Baumgartner 2002, pp 219-224; Hess 2005, pp 263-269; Brand 2003, pp 71-80.

${ }^{88}$ Letter regarding Preliminary Draft Hague Convention on Jurisdiction and the Enforcement of Civil Judgments, Jeffrey D Kovar, US Department of State Assistant Legal Adviser for Private International Law, to J.H.A. van Loon, Secretary General, Hague Conference on Private International Law, 22 February 2000, available at <http://www.cptech.org/ecom/hague/kovar2loon22022000.pdf> accessed 31 August 2015. See also Schulz 2006, pp 244-246.

${ }^{89}$ See Art. 27 and 31 Hague Choice of Court Convention. The EU had already signed the Convention in 2009, but the ratification was postponed primarily because of the ongoing recast of the Brussels I Regulation and the need to align the rules of these instruments.

${ }^{90}$ Art. 16 Hague Choice of Court Convention provides that the Convention applies to choice of court agreements concluded after the date of entry into force in that State, and shall not apply to proceedings instituted before its entry into force in the State of the court seized.

${ }^{91}$ Art. 1(1) and 3(a) Hague Choice of Court Convention.

${ }^{92}$ As is clear from 3(b) Hague Choice of Court Convention. This rule coincides with the extended scope of Art. 25 Brussels I-bis; see Section 3.2.
} 


\subsection{Regulatory framework}

The basic rules of the Hague Choice of Court Convention are straightforward: ${ }^{93}$ firstly, the choice of court must be an exclusive one within the meaning of Art. 3; secondly, it must be formally valid. According to Art. 3 of the Convention, a choice of court is formally valid if it was made in writing or by any other means of communication that renders information accessible so as to be usable for subsequent reference. This makes the scope of this Convention narrower than that of Art. 25 of the Brussels I-bis Regulation, which extends to non-exclusive choice of court agreements. Moreover, the formal requirements are stricter, since the reference to parties' practice and trade usages is not included.

The jurisdictional part includes two key rules, the first being Art. 5 of the Convention, which is aimed at the chosen court. According to this provision, the chosen court must assume jurisdiction in relation to an exclusive choice of court agreement that is formally valid pursuant to Art. 3, unless the agreement is null and void under the law of that State. The explanatory Hartley/Dogauchi report clarifies that this includes the choice of law provisions of that State. ${ }^{94}$ As discussed in Section 3.2, the Brussels I-bis Regulation includes a similar rule on the substantive validity. Since the Convention does not extend to consumer contracts and excludes several other types of disputes, including the ones for which the Brussels I-bis Regulation contains exclusive jurisdiction rules, there are no further exceptions to this rule. Art. 5(2) explicitly rules out lis pendens and forum non conveniens as grounds to refuse jurisdiction. ${ }^{95}$ The second key rule, Art. 6 of the Convention, mirrors this provision, and provides that all courts other than the one chosen must suspend or dismiss proceedings. There are five exceptions to this, and they pertain to the following: invalidity of the choice of court agreement; incapacity to conclude the agreement; manifestation of injustice or public policy; exceptional reasons for which the agreement cannot reasonably be performed; and situations in which the chosen court has decided not to hear the case.

The jurisdiction section of the Convention is complemented by Art. 7 concerning interim measures of protection. These are excluded from the scope of the Convention, and for this reason the Convention does not prohibit the granting of such measures by a court other than the one exclusively chosen. ${ }^{96}[45]$

A tremendous achievement reached by the Hague Choice of Court Convention is that judgments given by the court that was designated in an exclusive choice of court agreement will be recognised and enforced, in accordance with Art. $8 \mathrm{ff}$. Inherent to the global nature of the Convention, the rules are more restrictive than those of the Brussels I-bis Regulation, but it is a big step forward, since this is the first general Convention to establish a worldwide system of recognition and enforcement for judgments. ${ }^{97}$

\footnotetext{
${ }^{93}$ See inter alia Hartley 2013, pp 209-216; Schultz 2006, pp 250-265; Kruger 2006, pp 448-452; Kramer 2006a, pp 110-116; Rühl 2005, pp. 412-415.

94 Hartley and Dogauchi 2007, no 43.

${ }^{95}$ Art. 19 Hague Choice of Court Convention, however, does allow a State to make a declaration stating that it can refuse to accept jurisdiction if, with the exception of the location of the chosen court, there is no connection between that State and the parties or the dispute.

96 Provisional and protective measures are included in the Brussels I-bis Regulation, but are largely in effect since a choice of court agreement does not prohibit another court from granting a provisional or protective measure provided that it can derive jurisdiction from Art. 35 as interpreted in ECJ 17 November 1998, Case C-391/95, ECR 1998, I-7091.

97 In 2011, a renewed Judgment Project is undertaken by the Hague Conference on Private International Law, following earlier attempts to establish a worldwide judgement convention. See $<$ http://www.hcch.net/index en.php?act=text.display\&tid=149> accessed 31 August 2015. On the developments, see Beaumont 2014, pp 532-539.
} 


\subsection{Interaction with the Brussels I-bis Regulation}

During the negotiations on the Hague Choice of Court Convention the relationship with the other international instruments - and in particular the (then) Brussels I Regulation - was an important concern. The explanatory Hartley/Dogauchi report even designates it as 'one of the most difficult ones'. ${ }^{98}$ This might in part account for the cryptic formulation of Art. 26(6) of the Hague Choice of Court Convention. Priority is given to the Convention, where one party is resident in an EU Member State or in a third State that is not a member of the Hague Convention, and the other in a non-EU State that is a party to the Hague Convention, even if the parties designate the courts of an EU Member State. The Brussels I-bis Regulation remains applicable when none of the parties is resident in a State that is a party to the Hague Convention (provided they have chosen one of the Member State courts pursuant to Art. 25 Brussels I-bis).

As the rules of the Brussels regime are now aligned largely with those of the Hague Choice of Court Convention, the demarcation between these two international instruments has become less of an issue. They are mainly communicating vessels that in a similar manner secure party autonomy and contribute to the efficiency of international commercial litigation.

\section{Concluding remarks}

Party autonomy is a key principle in private international law, and also draws support and inspiration from other disciplines. Psychologically and sociologically, party autonomy has been considered an expression of the individuals' freedoms. [46] Law and economics considers party autonomy to be an important factor in improving the efficiency of laws and institutions, in decreasing the costs relating to transitions, and in the optimal allocation of resources. On the negative side, party autonomy can create externalities that might increase costs for society or third parties. Furthermore, the position of weaker parties might be in danger of potential abuse by parties whose negotiating power is stronger.

In the EU, party autonomy is considered important in furthering cross-border trade and facilitating the internal market, and it is a cornerstone of the Brussels I-bis Regulation. On the global level, the choice of court has found recognition with the establishment and the recent entry into force of The Hague Choice of Court Convention. It is a breakthrough towards a worldwide enforceability of choice of court agreements to the benefit of international commerce. It is hoped that the US and Ukraine will soon ratify the Convention; a number of other countries have already indicated their interest in its possible ratification. ${ }^{99}$

It must be noted that party autonomy also has its downsides, as it assumes an equal bargaining power that is often lacking in practice. In the Brussels regime, insofar as it concerns recognised weaker parties (insurance, consumer and employment contracts), this has been tackled by offering protection against imposed choice of court clauses. Moreover, the Brussels I Regulation with its strict lis pendens rule opened the door to litigation tactics torpedoing the effectiveness of choice of court agreements and litigation. It is certainly an improvement that the Brussels I-bis Regulation the risk of abusive litigation has been mitigated by reversing the lis pendens rule. As is the case in the Hague Choice of Court Convention, choice of court now takes priority over the first seized rule, giving way to the chosen court.

The new Brussels regime on choice of court and its extended territorial scope coupled with the Hague Choice of Court Convention will strengthen the international effectiveness of choice of court agreements. This increases legal certainly, and paves the way for a healthy

\footnotetext{
98 Hartley and Dogauchi 2007, no 25. See also Pertegás 2010, pp 22-23.

${ }_{99}$ Pertegás 2015, p 374. These include Australia, New Zealand, the People's Republic of China, and Serbia.
} 
competition between jurisdictions for the benefit of commercial parties seeking the optimal court in terms of, among other things, costs, reliability, quality, and applicable law. At the same time, the increased international enforceability of choice of court agreements makes court litigation a more viable alternative for parties that do not wish to opt for arbitration. ${ }^{100}$

Empirical evidence shows that party autonomy is in fact highly regarded in commercial practice, and a choice of court (choice of dispute resolution) clause is present in almost every commercial contract. As suggested by several surveys, in making a choice of court, parties consider a number of legal and practical factors to be the most important. However, the significance given to these factors does not explain fully why some jurisdictions (with special regard to England) are more attractive compared to others. Some scholars explain this by pointing out that parties in fact make their choice of court based primarily on market [47] conformity and perceived quality. The weight of these factors rather than the high quality of the legal rules might be disappointing, and are difficult to influence by countries. We consider that optimism should prevail, and academics should further their research into the factors that influence the choice of court. Ultimately, true party autonomy can be developed only by way of a better understanding of the process pertaining to choice of court and of the factors that influence it.

\section{Reference list}

Alpa G (2006) Harmonisation of and Codification in European Contract Law. In: Vogenauer S, Weatherill S (eds) The Harmonisation of European Contract Law: Implications for European Private Laws, Business and Legal Practice. Hart Publishing, Oxford, pp 149-170

Basedow J (2013) Exclusive Choice-of-Court Agreements as a Derogation from Imperative Norms. In: Lindskoug P, Manusbach U, Millqvist G et al (eds) Essays in Honour of Michael Bogdan. Juristförlaget, Lund, pp 15-31

Baumgartner SP (2002) The proposed Hague Convention on Jurisdiction and Foreign Judgments: Where We Are and the Road Ahead. European Journal of Law Reform 4:219-243

Beaton P (2012) Globalisation and Scottish Law. In: Kramer XE, van Rhee CH (eds) Civil Litigation in a Globalising World. T.M.C. Asser Press, The Hague, pp 263-176

Beaulier S (2005) Polycentrism and power: a reply to Warren Samuels. In: Stringham E (ed) Anarchy, State and Public Choice. Edward Elgar, Cheltenham, UK, pp 178-190

Beaumont P (2014) The revived Judgments Project in The Hague. NIPR 4:532-539

Brand RA (2014) The Evolving Private International Law / Substantive Law Overlap in the European Union. In: Mankowski P, Wurmnest W (eds) Festschrift für Ulrich Magnus zum 70. Geburtstag. Sellier European Law Publishers, Munich, pp 371-383

Brand RA (2003) Concepts Consensus and the Status Quo Zone: Getting to "Yes" on a Hague Jurisdiction and Judgments Convention. In Carmody C, Iwasawa Y and Rhodes S (eds) Trilateral perspectives on international legal issues: conflict and coherence. American Society of International Law, Baltimore, MD, pp 71-108

Dammann J, Hansmann H (2008) Globalizing commercial litigation. Cornell Law Rev 94(1):1-72

Dickinson A (2010) Surveying the Proposed Brussels I bis Regulation: Solid Foundations but Renovation Needed. In: Bonomi A, Romano GP (eds) Yearbook of Private International Law, vol XII. Sellier European Law Publishers, Munich, pp 247-310

Durand-Barthez P (2012) The "governing law" clause: legal and economic consequences of the choice of law in international contracts. International Business Law Journal - Revue de Droit des Affaires Internationales(5):505518

Eidenmüller H (2011) The Transnational Law Market, Regulatory Competition, and Transnational Corporations. In J Global Legal Stud 18(2):707-749

Evro L (2014) Nordic Court Culture in Progress: Historical and Futuristic Perspectives. In: Ervo L, Nylund A (eds) The Future of Civil Litigation. Springer International Publishing, Switzerland, pp 383-408

100 See also Schultz 2006, pp 267-268; Kramer 2006b, pp 171-172. 
Fentiman R (2007) Lis pendens - related actions. In: Magnus U, Mankowski P (eds) Brussels I Regulation, vol 1. Sellier. European Law Publishers, München, pp 475-522

Ferrero S (20 October 2014) Le clausole di elezione di foro e le convenzioni arbitrali "unilaterali". Recenti sviluppi nel panorama internazionale e spunti di riflessione nel diritto italiano. BusinessJus. Available via BusinessJus. http://www.businessjus.com/le-clausole-di-elezione-di-foro-e-le-convenzioni-arbitrali-unilaterali/. Accessed 31 August 2015

Garcimartin P (2015) Prorogation of Jurisdiction - Choice of Court Agreements and Submission (Arts. 25-26). In: Dickinson A, Lein E (eds) The Brussels I Regulation Recast. Oxford University Press, Oxford

Gottschalk E (2007) The Law Applicable to Intellectual Property Rights: Is the Lex Loci Protectionis a Pertinent Choice-of-Law Approach?. In: Gottschalk E, Michaels R, Rühl G et al (eds) Conflict of Laws in a Globalized World. Cambridge University Press, Cambridge, pp 184-219 [48]

Hartley T (2005) Choice-of-courts agreements, lis pendens, human rights and the realities of international business: reflections on the Gasser case. In: Jobard-Bachellier M, Mayer P (eds) Le droit international privé: esprit et méthodes: mélanges en l'honneur de Paul Lagarde. Dalloz, Paris, pp 383-392

Hartley T, Dogauchi M (2007) Explanatory Report on the 2005 Hague Choice of Court Agreements Convention. $\mathrm{HCCH}$ Publication, available at www.hcch.net/upload/expl37e.pdf

Hartley T (2013) Choice-of-court agreements and the new Brussels I regulation. Law Q Rev 129:309-317

Hess B, Pfeiffer T, Schlosser P (2007) Report on the application of regulation Brussels I in the member states. CF Müller, Heidelberg

Hess B (2005) The Draft Hague Convention on Choice of Court Agreements, External Competencies of the European Union and Recent Case Law of the European Court of Justice. In: Nuyts A and Watté N (eds) International Civil Litigation in Europe and Relations with Third States, Bruylant, Brussels, pp 263-284

Smits J (1998) A European Private Law as a Mixed Legal System. Maastricht Journal of European and Comparative Law 5:328-340

Kramer XE (2014) Competitie in de Europese civiele rechtsruimte: een spanningsveld in de grensoverschrijdende geschillenbeslechting? Tijdschrift voor Privaatrecht 51(4):

Kramer XE (2006a) Het nieuwe Haags Forumkeuzeverdrag: Een welkom compromis met vallen en opstaan. NIPR 24:109-118

Kramer XE (2006b), De forumkeuze als betrouwbaar alternatief voor het arbitraal beding in de internationale handelspraktijk? Het nieuwe Haags Forumkeuzeverdrag. NTHR:165-172.

Kramer XE, van Rhee CH (2012) Civil Litigation in a Globalising World: An Introduction. In: Kramer XE, van Rhee $\mathrm{CH}$ (eds) Civil Litigation in a Globalising World. T.M.C. Asser Press, The Hague, pp 1-16

Kruger T (2006) I. The 20th Session of The Hague Conference: A New Choice Of Court Convention And The Issue Of EC Membership. International and Comparative Law Quarterly 55(02):447-456

Low G (2013) A Psychology of Choice of Laws. European Business Law Review 24(3):363-387

Magnus U (2012) Choice of Court Agreements in the Review Proposal for the Brussels I Regulation. In: Lein E (ed) The Brussels I Review Proposal Uncovered. The British Institute of International and Comparative Law, London, pp 83-102

Michaels R (2008) Economics of Law as Choice of Law. Law Contemp Probl 71(3):73-105

Moser LGM (2015) Parties' preferences in international sales contracts: an empirical analysis of the choice of law. Unif L Rev 20:19-55.

Nielsen PA (2013) The New Brussels I Regulation. Common Market Law Review 50(2):503-528

Pertegás M (2015) Feeling the Heat of Disputes and Finding the Shade of Forum Selection. Nederlands Internationaal Privaatrecht: 374-375.

Pertegás M (2010) The Brussels I regulation and the Hague convention on choice of court agreements. ERA Forum 11:19-27

Peters A (2014) The Competition between Legal Orders. International Law Research 3(1):45-65

Rammeloo S (2003) The long and winding road towards freedom of establishment for legal persons in Europe. Maastricht journal of European and comparative law 10(2):169-197

Rühl G (2010) Choice of Law and Choice of Forum in the European Union: Recent Developments. Social Science Research Network. Available via SSRN. http://papers.ssrn.com/sol3/papers.cfm?abstract id=1604615. Accessed 31 August 2015 
Rühl G (2007) Party Autonomy in the Private International Law of Contracts: Transatlantic Convergence and Economic Efficiency. In: Gottschalk E, Michaels R, Rühl G et al (eds) Conflict of Laws in a Globalized World. Cambridge University Press, Cambridge, pp 153-183

Rühl G (2005) Das Haager Übereinkommen über die Vereinbarung gerichtlicher Zuständigkeiten: Rückschritt oder Fortschritt?. Praxis des Internationalen Privat- und Verfahrensrechts 25:410-415

Salecl R (2009) Society of choice. Differences 20(1):157-180

Salecl R (2012) Violence as a response to the ideology of choice. Cardozo Law Review 33(6):2275-2288

Schulz A (2006) The Hague Convention of 30 June 205 on Choice of Court Agreements. J Priv Int'I L 2(2):243-269

Schwartz B (2000) Self-determination: The tyranny of freedom. Am Psychol 55(1):79-88

Sieger LE (2011) Civil Rights. In: Chatterjee DK (ed) Encyclopedia of Global Justice. Springer Science+Business Media, pp 137-140 [49]

Smits J (1998) A European Private Law as a Mixed Legal System. Maastricht Journal of European and Comparative Law 5:328-340

Stone P (2014) EU Private International Law, 3rd edn. Edward Elgar Publishing, Cheltenham

Strong S (2014) Limits of Procedural Choice of Law. Brook.J.Int'I L. 39:1027-1121

Symeonides SC (2013) The Hague principles on choice of law for international contracts: some preliminary comments. American journal of comparative law 61(4):873-899

Thiele C (2007) The Hague Convention on Choice-of-Court Agreements: Was It Worth the Effort? In: Gottschalk E, Michaels R, Rühl G et al (eds) Conflict of Laws in a Globalized World. Cambridge University Press, Cambridge, pp 63-88

Tiebout CM (1956) A pure theory of local expenditures. The journal of political economy 64(5):416-424

Trachtman JP (1993) International regulatory competition, externalization, and jurisdiction. Harv.Int'I.LJ 34(1):47104

Visscher L (2012) A Law and Economics View on Harmonisation of Procedural Law. In: Kramer XE, van Rhee $\mathrm{CH}$ (eds) Civil Litigation in a Globalising World. T.M.C. Asser Press, The Hague, pp 65-91

Vogenauer S (2013) Regulatory competition through choice of contract law and choice of forum in Europe: Theory and evidence. In: Eidenmüller H (ed) Regulatory Competition in Contract Law and Dispute Resolution. Verlag C.H. Beck and Hart Publishing, pp 227-286

Vogenauer S, Weatherill S (2006) The European Community's Competence to Pursue the Harmonisation of Contract Law_an Empirical Contribution to the Debate. In: Vogenauer S, Weatherill S (eds) Studies of the Oxford Institute of European and Comparative Law. Hart Publishing, Oxford and Portland Oregon, pp 105-148

Wagner G (2013) Dispute Resolution as a Product: Competition between Civil Justice Systems. In: Eidenmüller H (ed) Regulatory Competition in Contract Law and Dispute Resolution. C.H.Beck, Nomos Verlagsgesellschaft, and Hart Publishing, Baden-Baden, Oxford, pp 347

Wauschkuhn JL (2014) Babel of international litigation: Court language as leverage to attract international commercial disputes. NIPR(3):343-350

Weller M (2015) Mutual trust: in search of the future of European Union private international law. Journal of Private International Law 11(1):64-102

Zimmer D (2000) Private International Law of Business Organisations. European Business Organization Law Review (EBOR) 1(3):585-599

Zimmermann R (2006) Contract Law Reform: The German Experience. In: Vogenauer S, Weatherill S (eds) The Harmonisation of European Contract Law: Implications for European Private Laws, Business and Legal Practice. Hart Publishing, Oxford, pp 71-88 